Journal of Business Venturing, Volume 23, Issue 6, November 2008, Pages 673-686

\title{
Does Self-Employment Reduce Unemployment?
}

\author{
A. Roy Thurik \\ Erasmus University Rotterdam, the Netherlands; EIM Business and Policy Research, Zoetermeer, the \\ Netherlands; and Max Planck Institute of Economics, Jena, Germany
}

\section{Martin A. Carree}

University of Maastricht, the Netherlands

\section{André van Stel}

EIM Business and Policy Research, Zoetermeer, the Netherlands; and Cranfield School of Management, Cranfield University, UK

\section{David B. Audretsch}

Max Planck Institute of Economics, Jena, Germany; and Institute for Development Strategies, Indiana University, USA

KEYWORDS: entrepreneurship, self-employment, unemployment.

JEL CLASSIFICATION: J23, J64, L26, L53, M13, O11

\section{ACKNOWLEDGEMENT:}

Address correspondence to Professor Roy Thurik, Centre for Advanced Small Business Economics, Erasmus School of Economics, Erasmus University Rotterdam, PO Box 1738, 3000 DR Rotterdam, the Netherlands, +31-10-4082232, thurik@few.eur.nl.

This paper is the result of a series of visits by David Audretsch as a Visiting Research Fellow at the Tinbergen Institute; by Roy Thurik and Martin Carree as Ameritech Research Scholars at the Institute for Development Strategies, Indiana University; and by André van Stel and Roy Thurik to the Max Planck Institute of Economics in Jena, Germany. Martin Carree is grateful to the Royal Netherlands Academy of Arts and Sciences (KNAW) for financial support. The authors acknowledge the comments of Adam Lederer, Maria Minniti and Lorraine Uhlaner. Starting with the descriptive Thurik (1999), this paper has evolved through many iterations while early versions have been presented at many workshops and conferences. Two anonymous referees provided valuable comments. The usual disclaimer applies. 


\begin{abstract}
This paper investigates the dynamic relationship between self-employment and unemployment rates. On the one hand, high unemployment rates may lead to start-up activity of self-employed individuals (the "refugee" effect). On the other hand, higher rates of self-employment may indicate increased entrepreneurial activity reducing unemployment in subsequent periods (the "entrepreneurial" effect). This paper introduces a new two-equation vector autoregression model capable of reconciling these ambiguities and estimates it for data from 23 OECD countries between 1974 and 2002. The empirical results confirm the existence of two distinct relationships between unemployment and self-employment: the "refugee" and "entrepreneurial" effects. We also find that the "entrepreneurial" effects are considerably stronger than the "refugee" effects.
\end{abstract}




\section{INTRODUCTION}

Linking unemployment to self-employment dates to at least Oxenfeldt (1943), who argues that individuals confronted with unemployment and low prospects for wage-employment will turn to self-employment as a viable alternative. This is an extension of Knight's (1921) view that individuals decide between three states - unemployment, self-employment and employment. Although the actual decision is shaped by the relative prices of these three activities, implied is the prediction of a positive correlation between self-employment and unemployment. This simple theory of income choice has been the basis for a range of studies focusing on the decision of individuals to become self-employed (Parker, 2004; Grilo and Thurik, 2005; Grilo and Irigoyen, 2006). Specifically, this theory suggests that increasing unemployment leads to increasing startup activity because the opportunity cost of starting a firm has decreased (Blau, 1987; Evans and Jovanovic, 1989; Evans and Leighton, 1990; Blanchflower and Meyer, 1994). This effect has been referred to as the unemployment push, refugee or desperation effect. There is, however, an important counterargument to this theory: The unemployed tend to possess lower endowments of the human capital and entrepreneurial talent needed to start and sustain a new firm. This, in turn, would suggest that high unemployment may be associated with a low degree of self-employment. High unemployment rates may also imply lower levels of personal wealth which also reduce the likelihood of becoming self-employed (Johansson, 2000; Hurst and Lusardi, 2004). Lastly, high unemployment rates may correlate with stagnant economic growth leading to fewer entrepreneurial opportunities (Audretsch, 1995; Audretsch, Thurik, Verheul and Wennekers, 2002).

The counterarguments above suggest that entrepreneurial opportunities are not just the result of the push effect (the threat) of unemployment but also of the pull effect produced by a thriving economy as well as by past entrepreneurial activities. Indeed, while some scholars argue that unemployment influences start-up activity, others claim that the reverse holds true. Firm start-ups hire employees, resulting in subsequent decreases in unemployment (Lin, Manser and Picot, 1998; Pfeiffer and Reize, 2000). Furthermore, increased entrepreneurial activity may influence country-wide economic performance (van Stel, Carree and Thurik, 2005). For example, entrepreneurs enter markets with new products or production processes (Acs and Audretsch, 2003). They also increase productivity by increasing competition (Geroski, 1989; Nickell, 1996; Nickell, Nicolitsas and Dryden, 1997). They also improve our knowledge of what is technically viable; what consumers prefer; and of how to acquire the necessary resources by introducing variations of existing products and services in the market. The resulting learning process speeds up finding the dominant design of product-market combinations. This learning does not just come from ex- 
perimenting entrepreneurs: Knowledge spillovers play also an important role (Audretsch and Keilbach, 2004). Lastly, entrepreneurs are inclined to work longer hours and more efficiently as their income is closely related to their working effort. (See Carree and Thurik (2003) for a survey of the (positive) effects of entrepreneurship on economic growth.) A counterargument to this view points out that low survival rates combined with the limited growth of most small firms implies that the employment contribution of start-ups is very low. As Geroski (1995) has documented, the penetration rate, or employment share, of new-firm start-ups is remarkably low. In other words, the contribution of entrepreneurial activities to the reduction of unemployment is very limited at best.

The available empirical evidence, unfortunately, presents similar ambiguities and reflects these two conflicting theories. Some studies have found that unemployment is associated with increased entrepreneurial activities while others have found that entrepreneurial activity and unemployment are inversely related (Thurik, 1999). Evans and Leighton (1990), for example, found that unemployment is positively associated with the propensity to start new firms, but Garofoli (1994) as well as Audretsch and Fritsch (1994) found that unemployment is negatively related to firm start-up. ${ }^{1}$ Carree (2002) found no statistically significant relationship between unemployment and the number of establishments. In reviewing early empirical evidence relating unemployment rates to new-firm start-up activity, Storey (1991, p. 177) concludes, "The broad consensus is that time series analyses point to unemployment being, ceteris paribus, positively associated with indices of new-firm formation, whereas cross sectional, or pooled cross sectional studies appear to indicate the reverse. Attempts to reconcile these differences have not been wholly successful." Audretsch and Thurik (2000) present empirical evidence that an increase in the number of business owners reduces the unemployment rate. They identify an "entrepreneurial" effect in terms of the positive impact on employment from new firm entry. However, Blanchflower (2000), examining OECD countries, finds no positive impact of self-employment rates on GDP growth. Carree, van Stel, Thurik and Wennekers (2002 and 2007) suggest that countries with relatively low self-employment rates benefit from increased self-employment in terms of GDP growth, but that countries with relatively high self-employment rates do not.

Consequently, there are not just theoretical reasons, but also empirical evidence, albeit contested, that while unemployment causes increased self-employment, self-employment causes reduced unemployment. Unravelling the relationship between self-employment and unemployment

\footnotetext{
${ }^{1}$ Other studies showing that greater unemployment serves as a catalyst for start-up activity include Reynolds, Miller and Maki, 1995; Reynolds, Storey and Westhead, 1994; Hamilton, 1989; Highfield and Smiley, 1987; Yamawaki, 1990; and Evans and Leighton, 1989 and 1990.
} 
is crucial because policy is frequently based on assumptions that do not reflect the described ambiguities. The purpose of the present paper is to try and reconcile the ambiguities found in the relationship between unemployment and start-up activity. We do this by introducing a simple twoequation vector autoregression model where changes in unemployment and self-employment are linked to subsequent changes in those variables for a panel of 23 OECD countries.

The organization of this paper is as follows. We start by providing additional background on the "entrepreneurial" effect and present an algebraic model which forms the basis for our regression exercises. In the following sections the algebraic model is extended to a two-equation vector autoregression (VAR) model, which will be used to test the "entrepreneurial" and "refugee" effects. We also present the data and methodology employed to estimate the VAR model. Finally, in the last two sections we discuss the estimation results and draw conclusions.

\section{LINKING SELF-EMPLOYMENT TO UNEMPLOYMENT}

As discussed previously, there may be both a (positive) effect of unemployment on selfemployment (the "refugee" effect) and a (negative) effect of self-employment on unemployment (the "entrepreneurial" effect). And both possibilities have been studied theoretically and empirically. The "entrepreneurial effect," however, requires some further analysis.

Why an increased amount of entrepreneurial activity should have an impact on unemployment? The economics literature on Gibrat's Law provides one approach to address this question. Gibrat's Law states that firm growth is independent of firm size. Thus, Gibrat's Law implies that shifting employment from large to small enterprises should have no impact on total employment, since the expected growth rates of both types of firms are identical. And, as a result, restructuring the economy from large to small enterprises (including the self-employed) should have no impact on the overall unemployment rate.

However, there is strong and systematic empirical evidence suggesting that, in fact, Gibrat's Law does not hold across a broad spectrum of firm sizes. Sutton (1997) and Caves (1998) have produced two comprehensive and exhaustive compilations of studies relating firm size to growth and have shown that stylised fact (as Geroski (1995) puts it) that smaller firms have greater growth rates than their larger counterparts. Beginning with the pioneering studies by Evans (1987a and 1987b) and Hall (1987), along with Dunne, Roberts, and Samuelson (1988 and 1989), a central finding of this literature is that firm growth is negatively related to firm size and 
age. ${ }^{2}$ These findings have been confirmed in virtually every subsequent study undertaken, despite differences in country, time period, industry, and methodology used. The evidence strongly supports the claim that very young and very small firms outperform their older and larger counterparts in terms of employment creation even when corrected for their higher probabilities of exit. Some studies indicated that age and size effects disappear as firms' age and employment increase (Hart and Oulton, 1999).

The literature described above uses micro level data and shows that small firms grow faster than large firms. This suggests that, at the macro or country level, a larger presence of small firms contributes positively to economic performance as well. Self-employment rates represent a specific measure of the presence of small and very small firms in an economy. However, it is not clear that higher self-employment rates automatically lead to improved economic performance. In fact, self-employment rates in some countries may be inefficiently high (Carree, van Stel, Thurik and Wennekers, 2002 and 2007). Too much self-employment can be characteristic of poor economies of scale in production and R\&D rather than of vibrant entrepreneurial activity. Within this context, Carree et al. have introduced a model where an 'optimal' level of self-employment, $E_{i}^{*}$, is assumed to exist for each country $i$, dependent on its stage of economic development. The level $E_{i}^{*}$ is optimal in the sense that both a level of self-employment $E_{i}$ lower than $E_{i}^{*}$ and a level of self-employment higher than $E_{i}^{*}$ leads to a lower rate of economic growth compared to a situation where $E_{i}$ equals $E_{i}^{*}$. In the first case, competition levels are too low, while in the second case, economies of scale and scope are not fully utilised. ${ }^{3}$

Similarly to their work, in the present paper we assume that the unemployment rate $U_{i t}$ in country $i$ and period $t$ is positively affected by the extent to which the self-employment rate $E_{i, t-1}$ is different from the country-specific optimal rate (in terms of employment creation), $E_{i}^{*}$. The unemployment rate is equal to the level $U_{i t}^{o}$ that would be present in case the actual selfemployment rate would be equal to the optimal rate $\left(E_{i, t-1}=E_{i}^{*}\right)$ plus a penalty determined by the absolute difference between $E_{i, t-1}$ and $E_{i}^{*}$ :

(1) $U_{i t}=U_{i t}^{o}+\varsigma\left|E_{i, t-1}-E_{i}^{*}\right|$,

\footnotetext{
${ }^{2}$ See Klomp, Santarelli and Thurik (2006) for a survey of the empirical literature.

${ }^{3}$ Carree, van Stel, Thurik and Wennekers (2002) provide empirical support for this model using a data set which is similar to the one used in the present analysis.
} 
where $\varsigma>0$. Taking the first difference of equation (1) gives

(2) $U_{i t}-U_{i, t-1}=\varsigma\left(\left|E_{i, t-1}-E_{i}^{*}\right|-\left|E_{i, t-2}-E_{i}^{*}\right|\right)+\varepsilon_{i t}$,

where $\varepsilon_{i t}=\Delta U_{i t}^{o}$ stands for the effect of business cycle and other factors (with exception of the self-employment rate variable) on the rate of unemployment. The optimal self-employment rates are determined by institutional and socio-economic factors and, hence, only change very slowly over time. Therefore, there are three relevant cases for the relation between the self-employment rate and the country-specific optimal rate. First, both the self-employment rate in period t-1 and t2 are higher than the optimal rate (case 3a). Second, they are both less than the optimal rate (case $3 b)$. Third, one is higher than the optimal rate and one is lower, while both are relatively close to the optimal rate (case $3 \mathrm{c}$ ): $E_{i, t-1} \approx E_{i, t-2} \approx E_{i}^{*}$. Depending upon the case, equation (2) changes as follows:

(3a) $E_{i, t-1}>E_{i}^{*} \wedge E_{i, t-2}>E_{i}^{*}: \Delta U_{i t}=\varsigma \Delta E_{i, t-1}+\varepsilon_{i t}$,

(3b) $E_{i, t-1}<E_{i}^{*} \wedge E_{i, t-2}<E_{i}^{*}: \Delta U_{i t}=-\varsigma \Delta E_{i, t-1}+\varepsilon_{i t}$,

(3c) $E_{i, t-1}>E_{i}^{*}>E_{i, t-2} \quad \vee \quad E_{i, t-1}<E_{i}^{*}<E_{i, t-2}: \quad \Delta U_{i t} \approx \varepsilon_{i t}$

Equations (3a) through (3c) show that the sign of the coefficient of $\Delta E_{i, t-1}$ reflects whether, on average for the countries under consideration, the self-employment rate is below, above or about equal to the optimal level. When the coefficient is positive, the self-employment rate is too high (case 3a), while if the coefficient is negative, then the self-employment rate is too low (case $3 b)$. In case there is no effect of $\Delta E_{i, t-1}$ on $\Delta U_{i t}$ then the self-employment rate should be close to the optimal level (case 3c). ${ }^{5}$ We use equation (4) to test for the effect:

(4) $U_{i t}-U_{i, t-1}=\beta\left(E_{i, t-1}-E_{i, t-2}\right)+\varepsilon_{i t}$.

The effect of self-employment rates on unemployment rates is the "entrepreneurial" effect of increased entrepreneurial activity contributing to lower unemployment rates. The coefficient $\beta$ can be either positive or negative, while the coefficient $\varsigma$ introduced in equation (1) must be positive. The expected sign of $\beta$ is negative though. That is, we expect that, for the majority of countries in our data base, self-employment levels are below optimum (case $3 b$ ) so that an in-

\footnotetext{
${ }^{4}$ See Audretsch, Carree, van Stel and Thurik (2002) for a similar approach relating economic growth to small firm presence in 17 European countries.

${ }^{5}$ The intuition is that in case the actual self-employment rate changes from just below the optimal level to just above, or the other way around, this change has no net positive or negative effect on economic performance, here the rate of unemployment.
} 
crease of self-employment results in a subsequent decrease in unemployment. We supplement our main equation (4) with the complementary equation relating the change of the unemployment rate to the subsequent change in the self-employment rate:

(5) $E_{i t}-E_{i, t-1}=\lambda\left(U_{i, t-1}-U_{i, t-2}\right)+\eta_{i t}$

The effect of unemployment rates on self-employment rates is the push ("refugee") effect of recently unemployed workers starting their own venture to escape unemployment. Coefficient $\lambda$ is expected to be positive.

The ambiguity in the relationship between self-employment and unemployment is reflected by the opposite (expected) signs of the parameters in equations (4) and (5). We expect $\beta$ to be negative but $\lambda$ to be positive. Hence, although there is both a positive and a negative association between self-employment and unemployment, the model formed by equations (4) and (5) enables us to unravel the complex relationship. In the model and method section equations (4) and (5) will be extended to a simple VAR-model, which will be estimated using a data base of 23 OECD countries over the period 1974-2002. ${ }^{6}$ Also, although the period length is left undefined in the mathematical version of the model, in our empirical application, one period is defined as four years.

\section{MEASUREMENT ISSUES}

Following Storey (1991), we operationalize entrepreneurial activity in terms of the number of self-employed. More precisely, we use the change in the number of non-agricultural selfemployed (unincorporated as well as incorporated) as a fraction of the labour force. This measure has two significant advantages: First, while not being a direct measure of entrepreneurship, it is a useful and well-established proxy for entrepreneurial activity (Storey, 1991). Second, it is available for a large number of countries and, after applying appropriate harmonizations (van Stel, 2005), it can be compared across countries and over time. Of course, some important qualifications should be emphasized when using and interpreting this variable. First, the variable combines heterogeneous activities across a broad spectrum of sectors and contexts into one single measure. This measure treats all businesses as the same, both high- and low-tech. Second, the data are not weighted for magnitude or impact: all self-employed businesses are identically

\footnotetext{
${ }^{6}$ Note that equations (4) and (5) are in first differences, so that country-specific effects are differenced out. It is obvious that the rate of new venture formation is country-specific since for example entrepreneurial traits may be culture-dependent (Mueller and Thomas, 2000, and Shane, Kolvereid and Westhead, 1991).
} 
measured, even though some clearly have a greater impact than others. Third, this variable measures the relative change in the stock of self-employed businesses and not new start-ups. ${ }^{7}$

The panel data set of unemployment and self-employment rates for the 23 OECD countries for the 1974-2002 period is constructed as follows: For the unemployment data, $U$, we use the standardized unemployment rate of the OECD Main Economic Indicators. The data for selfemployment, $E$, are from the Compendia 2002.1 data set of EIM in Zoetermeer, The Netherlands. The Compendia data set uses data from the OECD Labour Force Statistics and other (countryspecific) sources to make the self-employment data as comparable as possible across countries and over time. ${ }^{8}$ The data in Compendia are available on a bi-annual (even years only) basis. Because our focus in the current paper is the effect of self-employment on unemployment, in Table 1 we show some data of the six country/period combinations (out of 46) with the highest and lowest values of the change in the self-employment rate from 1978 to 1986 and from 1986 to 1994. Out of six countries with the strongest increase in self-employment five show a subsequent decrease in unemployment. Italy is the exception. ${ }^{9}$ Out of six countries with the strongest decrease in self-employment five show a subsequent increase in unemployment. Portugal, with a substantial net inflow of EU funds ('Cohesion Funds') which probably exerts a downward pressure on unemployment rates, is the exception.

\section{TABLE 1 ABOUT HERE}

\section{MODEL AND METHOD}

The previous sections explain why the dynamic interrelationship between changes in selfemployment and unemployment is complex, and, in particular, why the direction of causality be-

\footnotetext{
${ }^{7}$ Basically, our measure of change in self-employment rate is a measure of net entry of entrepreneurs (i.e. the number of entrepreneurs starting a new business in a given period minus the number of entrepreneurs closing their business). Indeed, our measure of net changes in self-employment may or may not correlate with (gross) measures of entrepreneurial activity available from other sources. For instance, the correlation between the change in the self-employment rate over the period 2002-2004 and the Total-early-stage Entrepreneurial Activity (TEA) Index 2004 of the Global Entrepreneurship Monitor is 0.374 (pvalue 0.105; correlation based on 20 countries). See Acs, Arenius, Hay and Minniti (2005). Note that correlations may not be high as our measure is a net measure of entrepreneurial activity and not a gross measure. For example, in the US economy both entry and exit levels are relatively high. However, the net change in the self-employment rate has been relatively low in the last decades.

${ }^{8}$ In Compendia, self-employment rates are defined as the number of non-agricultural self-employed (unincorporated as well as incorporated), as a fraction of total labor force. The harmonizations mainly concern corrections for the number of incorporated self-employed (harmonization across countries) and corrections for trend breaks (harmonization over time). The 23 countries included in Compendia are the (old) EU-15 as well as Iceland, Norway, Switzerland, USA, Japan, Canada, Australia and New Zealand. See van Stel (2005) for details about the Compendia data base.

${ }^{9}$ Italy has a very high self-employment rate, approaching $20 \%$ in the first decade of the $21^{\text {st }}$ Century. Further increases in this rate may be counter-productive (Carree, van Stel, Thurik and Wennekers, 2002). On the other hand, the strong decrease in unemployment in Ireland between 1994 and 2002 cannot entirely be attributed to the increase in self-employment between 1986 and 1994. The strong economic performance of Ireland can also be attributed to factors like foreign direct investments and European Union subsidies. The Netherlands is an example of a country with decreasing self-employment rates $(-0.5 \%$ point between 1978 and 1986) and subsequently decreasing unemployment rates (-3.6\% point between 1986 and 1994). The appraised Dutch 'Poldermodel', which was launched by the 1982 Wassenaar Treaty between employers' organizations and unions, is an important reason for the huge decrease in unemployment during the late 1980s and the 1990s in The Netherlands (Thurik, 1999). Therefore, entrepreneurial activity is not the only route to achieving low unemployment rates.
} 
tween the two variables is not clear a priori. The previous sections suggest two testable hypotheses - that increases in self-employment rates lead to a decrease in subsequent unemployment, and that increases in unemployment rates lead to an increase in subsequent self-employment. In order to evaluate the causal linkages involved in the relationship, the most natural way of testing these two hypotheses is to estimate a vector autoregression (VAR) model (for example, see Sims, 1980). This means that a vector of dependent variables is explained by one or more lags of the vector of dependent variables, i.e. each dependent variable is explained by one or more lags of itself and of the other dependent variables. ${ }^{10}$

In our application, we have a two equation VAR model with the change in unemployment and the change in self-employment as dependent variables. Equations (4) and (5) are extended in three respects in order to obtain a testable empirical model. First, we include lagged dependent variables on the right hand side in the VAR model to test for the direction of causality. We will report Granger-causality test statistics when discussing our results. ${ }^{11}$ Second, we allow for multiple time lags as the "entrepreneurial" and "refugee" effects may come with a lag and we do not know a priori how long this lag may be. Third, we use time dummies as additional explanatory variables. These dummies correct for business cycle effects over the sample period for the countries covered by our dataset. The model reads as follows:

(6) $U_{i t}-U_{i, t-L}=\alpha+\sum_{j=1}^{J} \beta_{j}\left(E_{i, t-j L}-E_{i, t-(j+1) L}\right)+\sum_{j=1}^{J} \gamma_{j}\left(U_{i, t-j L}-U_{i, t-(j+1) L}\right)+\sum_{t=1}^{T} \delta_{t} D_{t}+\varepsilon_{1 i t}$
(7) $E_{i t}-E_{i, t-L}=\kappa+\sum_{j=1}^{J} \lambda_{j}\left(U_{i, t-j L}-U_{i, t-(j+1) L}\right)+\sum_{j=1}^{J} \mu_{j}\left(E_{i, t-j L}-E_{i, t-(j+1) L}\right)+\sum_{t=1}^{T} v_{t} D_{t}+\varepsilon_{2 i t}$, where $i$ is a country-index, $L$ is the time span in number of years, $J$ is the number of time lags included, $D_{t}$ are time dummies and $\varepsilon_{1 i t}$ and $\varepsilon_{2 i t}$ are possibly correlated error terms. The expected sign of the joint impact of the $\beta$ coefficients is negative and the expected sign of the joint impact of the $\lambda$ coefficients is positive.

Using the panel data set consisting of 23 OECD countries between 1974-2002, equations (6) and (7) are estimated using weighted least squares. We consider changes in self-employment

\footnotetext{
${ }^{10}$ Note that, because the same list of independent variables appears in both equations, OLS and SUR estimation are identical: it is not necessary to take into account possible correlation between the two error terms.

${ }^{11}$ Equations (6) and (7) can be used for testing Granger-causality. The Granger (1969) approach to the question of whether $x$ causes $y$ is to establish how much of the current $y$ can be explained by past values of $y$ and then to establish whether adding lagged values of $x$ can improve the explanation. $y$ is said to be Granger-caused by $x$ if $x$ helps in the prediction of $y$, or equivalently if the coefficients on the lagged $x$ 's are statistically significant. This can be tested using a simple F-test on the lagged $x$ 's.
} 
and unemployment over periods of four years, i.e. $L$ equals $4 .^{12}$ Furthermore, we test for the number of time lags, in order to gain insight into the lag structure between unemployment and self-employment. Inclusion of more lags seems relevant because the employment impact of entrepreneurial ventures is not instantaneous: it requires a number of years for the firm to grow. In this respect Geroski (1995, p. 148) notes that "Even successful entrants may take more than a decade to achieve a size comparable to the average incumbent." Beesley and Hamilton (1984) point at the seedbed role of new and small firms challenging incumbent firms. The essentially innovative seedbed activities, with the inevitable trial and error (birth and death) mechanism, may take a long time to cause the 'creative destruction' of incumbent enterprise, the emergence of new enterprise and subsequent growth. Audretsch (1995) shows that the share of total employment accounted for by a cohort of new-firm start-ups in U.S. manufacturing more than doubles as the firms age from two to six years.

Rather than imposing a lag structure for the impact of the lagged variables in equations (6) and (7), we test for the statistically most adequate lag structure by using likelihood ratio tests. We start by including only one lag, and then, one lag at a time, we include further lags until the likelihood ratio test rejects inclusion of further lags. In terms of equations (6) and (7), this procedure determines the value of $J$. We avoid using data for overlapping periods as this may cause a downward bias in the estimated standard errors of the coefficients. In other words, given that we chose $L$ equal to 4 , this implies that we use data for 2002, 1998, 1994, .., 1974.

\section{EMPIRICAL RESULTS}

Estimation results for the two-equation VAR model consisting of equations (6) and (7) are reported in Table $2 .^{13}$

\footnotetext{
${ }^{12}$ Given that our data are available on a bi-annual basis, the minimum lag length is two years. However, if we measure the variables over two-year periods, chances are that two consecutive periods fall within the same business cycle. An important disadvantage then is that the lagged dependent variable dominates the regression outcomes. Regressions using $L=2$ are available upon request. With the exception of Model Ia, these produced $\mathrm{R}^{2}$-values considerably lower than the values reported in the upper half of Table 2.

${ }^{13}$ Before starting our regression analysis we tested whether the dependent variables in our model are stationary. In particular, we tested for unit roots using the Dickey-Fuller method (Dickey and Fuller, 1979) and found no evidence for a unit root. More specifically we applied a t-test for $\rho$ in the augmented Dickey-Fuller regression

$\Delta_{4} y_{t}=\alpha+\beta t+\rho y_{t-4}+\lambda_{1} \Delta_{4} y_{t-4}+\ldots+\lambda_{p-1} \Delta_{4} y_{t-4(p-1)}+\varepsilon_{t}$ where $y_{t}$ is the four-year change in unemployment or self-employment, $t$ is a time trend, and $\rho$ is the order of the autoregressive (AR) process. For each dependent variable we ran nine variants, assuming AR processes of order one, two or three, and assuming that the AR process has no constant and no trend (i.e. $\alpha=\beta=0$ ), a constant but no trend ( $\beta=0$ ) or both a constant and a trend. The t-values for $\rho$ varied from 6.6 to -14.3 for the change in unemployment series, and from -4.2 to -8.2 for the change in self-employment series. As these values are well below the (negative) critical values, the null hypothesis of a unit root was rejected. Note that this is in line with expectations given that our dependent variables are in first differences.
} 


\section{TABLE 2 ABOUT HERE}

As explained above, initially we include only one lag of the dependent variables (Model Ia). We compute the coefficients using the largest possible sample, given the lag structure. As the oldest year in the data set is 1974 and using one lag implies going back eight years, we can use data for 1982, 1986, up to 2002. For each year we have 23 countries, which gives us 138 observations in Model Ia. From the results for equation (6) we find that changes in self-employment have a significantly negative impact on unemployment in the subsequent period. Indeed, the Grangercausality test indicates that self-employment causes unemployment to decrease (p-value below 0.05). From the results for equation (7), we see that in Model Ia, unemployment does not Granger-cause self-employment to increase.

However, results using Model Ia may be biased because our lag structure is too restrictive. As previously noted, considerable lags may be involved in the relationship. To test this we include a second lag, representing changes in unemployment or self-employment between t-12 and t-8 (basically an eight year lag). Using the extra lag implies that we lose a year in our sample, hence the model is estimated for 115 observations (Model IIa). We apply a likelihood ratio test to see whether including the extra lag improves the statistical fit of the model. For this purpose we re-compute the one lag model using the 115 observations sample (Model Ib). Testing Model IIa against Model $\mathrm{Ib}$ gives a likelihood ratio test statistic of 24.0. As the critical value at $5 \%$ level is 9.5 (four restrictions), it implies that a model using two lags is to be preferred over a model using one lag. Analogously, testing Model III against Model IIb we conclude that adding a third lag to the model does not improve the statistical fit. Hence, we conclude that model variants using two lags are statistically superior. Focusing on the results of Models IIa and IIb, we find that selfemployment Granger-causes unemployment to decrease, and also that unemployment Grangercauses self-employment ( $\mathrm{p}$-values below 0.05 in all four cases) to increase.

From the signs of the coefficients and t-values in Models IIa and IIb it appears that entrepreneurial activity, as hypothesized, reduces unemployment but that the impact appears after an eight year lag. The positive effect of unemployment on self-employment seems to capitalize somewhat faster. However, given the interrelationship between the two variables in the model, a more insightful way to capture the impact is to use impulse response functions. These functions capture and compute the impact over time of an exogenous shock in either of the dependent variables, taking into account the interrelationships reflected by the estimated system of equations. In Table 3 we present the impulse response function for a unit shock to entrepreneurial activity (impact on unemployment) and for a unit shock to unemployment (impact on entrepreneurial activity) for Model IIa. Focusing on equation (6) we see that the direct effect is greatest for the second 
period of four years. For instance, a one percent point increase in the self-employment rate brings down the unemployment by 1.12 percent point eight years later. The time pattern of the effect of self-employment on unemployment is illustrated in Figure 1, which pictures the impulse response function for Model IIa. The cumulative effect converges to -1.29 (note that Figure 1 relates to the direct effect).

\section{TABLE 3 ABOUT HERE}

\section{FIGURE 1 ABOUT HERE}

Table 3 shows that the initial impact of more entrepreneurial activity on unemployment is positive. Perhaps, initially, the increased competition by new entrants leads to higher labour productivity at the industry level, while industry output remains constant (Fritsch and Mueller, 2004). This implies a negative effect on employment. After some time, the new entrants may grow and actually contribute to economic growth. ${ }^{14}$ One must be careful with this type of conclusions as t-values for the one lag self-employment variables are low, as shown in Table 2.

The finding that countries with a greater increase in entrepreneurial activity also experience systematically higher employment growth rates may be linked to a Schumpeterian process of new and small firms generating new products and production processes with the consequence that older products and production processes are replaced. This Schumpeterian process is driven by a sequence of independent and isolated opportunities (Sutton, 1997, p. 48). In the Kirznerian perspective (Kirzner, 1973), entrepreneurship is the response to these previously undiscovered profit opportunities. ${ }^{15}$ This may lead to increased consumer satisfaction at a lower cost, hence to economic growth and lower unemployment. Profit opportunities might not only spur entrepreneurial activity but may also be generated by entrepreneurs starting new firms. This idea dates to Schumpeter (1934) and Hayek (1945): modern decentralized economies allow individuals to act on their entrepreneurial views and allow them to be rewarded.

Table 3 shows that changes in unemployment have a positive impact on subsequent selfemployment. This is in line with earlier findings as documented in the introduction. This is the "refugee" effect of unemployment: it stimulates start-up and self-employment rates. Our results indicate that the impact of a one percent point increase in unemployment leads to a 0.16 percent

\footnotetext{
${ }^{14}$ In their study of new business formation and regional development over time Fritsch and Mueller (2004) find that the peak of the positive impact of new businesses is reached about eight years after entry. This is similar to the time lag in our study. Fritsch and Mueller, however, apply the Almon lag model and discriminate between indirect effects of new business formation (crowding out of competitors, improvement of supply conditions and improved competitiveness) and a direct effect (the jobs created in the new businesses). See also Carree and Thurik (2007) and van Stel and Suddle (2007).

${ }^{15} \mathrm{See} \mathrm{Yu}$ (1998) for an examination of the role of adaptive entrepreneurship and its role in the dynamics of Hong Kong's economy.
} 
point increase in self-employment after eight years. Note that the "refugee" effect is considerably smaller than the "entrepreneurial" effect, i.e. the magnitude of the impacts in the right part of Table 3 is much smaller compared to the effects reported in the left part of the table.

\section{Testing for Coefficient Heterogeneity}

The set-up of our model assumes that the relationships are identical across the countries in our estimation sample. In this subsection we test for coefficient heterogeneity across countries for the intercept terms and the coefficients reflecting the "entrepreneurial" and "refugee" effects, i.e. coefficients $\alpha, \beta, \kappa$ and $\lambda$ in equations (6) and (7). For the intercept terms $\alpha$ and $\kappa$ we apply likelihood ratio (LR) tests to investigate whether inclusion of country dummies improves the model fit. Regarding coefficients $\beta$ and $\lambda$ we multiply the corresponding self-employment and unemployment variables with per capita income and include these cross-terms as additional variables in the model. ${ }^{16}$ This way we test whether the "entrepreneurial" and "refugee" effects vary with the development level of a country. For example, van Stel, Carree and Thurik (2005) find that the effect of entrepreneurial activity (TEA) on economic growth is higher for highly developed countries than for less developed countries. We may find a similar dependence on per capita income in the current analysis. All tests are conducted relative to Model IIa, the statistically preferred model in Table 2.

Regarding equation (6) where the change in unemployment is to be explained, we find no evidence for country-specificity of the intercept term $\alpha$. The LR test statistic equals 23.1 while the critical value at the 5\% significance level equals 33.9. Interestingly, when adding the multiplicative variable $\left(E_{t-8}-E_{t-12}\right) \times Y C A P_{t-8}$ to model specification IIa, this cross-term is significant at the $5 \%$ level and an LR test supports inclusion of this variable. ${ }^{17}$ The coefficients imply that the effect of the variable $E_{t-8}-E_{t-12}$ can be written as $1.468-0.173 Y C A P_{t-8}$. Hence, the (negative) impact of entrepreneurial activity on unemployment increases with per capita income. To give an impression of the variation across countries, per capita income values for 1994 imply an effect of 0.18 for Greece and an effect of -2.50 for the United States. In conformity with van Stel, Carree and Thurik (2005) we see that the "entrepreneurial" effect is greater for higher developed countries.

\footnotetext{
${ }^{16}$ We use real per capita income levels in thousands of US dollars, harmonized across countries using purchasing power parities.

${ }^{17} \mathrm{We}$ also estimated specifications including the multiplicative term corresponding to one lag (i.e. $\left.\left(E_{t-4}-E_{t-8}\right) \times Y C A P_{t-4}\right)$, both added separately and simultaneously with the two lag cross-term. In addition, we estimated specifications including the per capita income variable. All these alternative specifications turned out to be statistically inferior to the one solely adding the two lag cross-term to Model IIa.
} 
Regarding equation (7) where the change in self-employment is to be explained, we find evidence that coefficient $\kappa$ varies by country. Inclusion of country dummies significantly improves the model fit. The LR test statistic equals 40.9 for a critical value of 33.9. Closer inspection of the dummy coefficients reveals that France and Japan have the two highest coefficients, in the absolute sense. The two countries are exceptional: the self-employment rate in these countries has been continuously declining since the 1970s. When we include country dummies for France and Japan only, $R^{2}$ equals 0.489 (compared with 0.385 in Table 2). Coefficients and t-values of the unemployment variables are similar to Model IIa in Table 2 though: 0.067 (t-value 2.3) for the one lag variable and 0.083 for the two lag variable (t-value 2.7). Hence the magnitude of the "refugee" effect is robust: the inclusion of country dummies makes no difference. Finally, no evidence is found for heterogeneity of the $\lambda$ coefficients in that they depend upon per capita income levels.

\section{CONCLUSIONS}

The small business sector, and hence self-employment, has become increasingly important to modern OECD economies as they attempt to generate economic growth and employment. New and small firms have emerged as a major vehicle for entrepreneurship to thrive (Audretsch and Thurik, 2001). The present paper shows the important role that changes in self-employment can play in reducing unemployment.

As public policy turned to entrepreneurship to generate employment and economic growth, policy makers have turned to the academic literature seeking guidance. The advice they have found is ambiguous at best, conflicting and contradicting at worst. While some studies find a positive link between unemployment and start-up or self-employment rates, as a result of what we refer to in this paper as the "refugee" effect, other studies find evidence supporting a negative link between unemployment and start-up or self-employment rates, as a result of what we call the "entrepreneurial" effect. These two findings suggest radically different policy approaches. On the one hand, the literature focusing on the decision to become an entrepreneur suggests that public policy can reduce unemployment by providing instruments to promote entrepreneurship but does not necessarily stimulate economic growth. This literature implies policies encouraging the unemployed to become entrepreneurs. On the other hand, literature suggesting that by generating economic growth, entrepreneurship will mitigate unemployment results in policy focusing on instruments inducing high-growth entrepreneurship. The disparate recommendations resulting from 
these literatures have resulted in ambiguous implications for public policy concerning entrepreneurship.

Even further ambiguities emerging from the literature concerning the link between selfemployment and unemployment involve the business cycle. Studies reveal a positive impact of economic downturns, which encourages unemployed workers to become self-employed, but also a positive impact of economic upturns, where growth opportunities induce an increase in entrepreneurial activity. The unemployed do not enjoy the benefits of a paid job and will tend to search for one, "pushing" people into self-employment. However, low unemployment is likely to coincide with a lively market demand for products and services "pulling" the (un)-employed towards self-employment (Parker, 2004). Thus, there is both a "recession-push" and a "prosperitypull" aspect of the relation between unemployment and self-employment.

Overall, the relationships between self-employment and unemployment are fraught with complexity resulting in confusion and ambiguity for both scholars and policy makers. This paper attempts to unravel these complex relationships. Explicitly modelling self-employment and unemployment within the context of a simultaneous relationship, this paper uses a rich data set of OECD countries for a recent period to identify that the relationship between unemployment and self-employment is, in fact, both negative and positive. Changes in unemployment clearly have a positive impact on subsequent changes in self-employment rates. At the same time, changes in self-employment rates have a negative impact on subsequent unemployment rates. The latter is even stronger than the former. Because these are dynamic inter-temporal relationships, previous studies estimating contemporaneous relationships have confounded what are, in fact, two relationships each working in opposite directions and with different time lags. Our model shows that it is crucial to allow for different and variable time lags. It shows that both the effect of selfemployment on unemployment and that of unemployment on self-employment are rather long. This is one of the reasons why policy makers - favouring quick responses and results - have been slow to discover the prominent role of entrepreneurship in the economy.

An additional finding of our analyses is that the impact of entrepreneurial activity on macro-economic performance increases with per capita income. This is also found in van Stel, Carree and Thurik (2005) where an entirely different data set is used. Hence, the many policy initiatives of the highly developed European countries to stimulate entrepreneurship seem justified.

One limitation of our research, which is inherent to working with country data, is that we cannot directly trace the factors that influence the probability of moving from unemployment to self-employment at the micro level. For instance, heterogeneity across individuals (concerning 
education, former experience, etc.) is of great importance when we want to explain the success rate of exiting unemployment. Likewise, concerning the "entrepreneurial" effect, we know that heterogeneity across individuals plays a role as well. For instance, research at the micro level shows that education levels of entrepreneurs positively influence the probability of achieving firm growth (Congregado, Golpe and Millán, 2005). In our study this heterogeneity is aggregated away into self-employment and unemployment statistics at the country level. This shortcoming can only in a limited way be addressed by incorporating possible additional variables determining self-employment and unemployment rates, thereby extending the VAR-model to a VARX-model.

Notwithstanding the above limitation, the results of this study are of significant policy importance because policy often aims at achieving desirable effects at the economy-wide level. For this purpose it is important to understand the relations at the macro-economic level, as studied in the present paper. For instance, Germany, a country with high unemployment, recently adopted policies designed to encourage unemployed individuals to exit unemployment by selfemployment (Audretsch, Grilo and Thurik, 2007). However, as the current paper shows that the "refugee" effect is relatively small, one might wonder if such policies are worthwhile. Based on the larger "entrepreneurial" effect we suggest that it might be more effective to encourage entrepreneurship in general as higher levels of entrepreneurial activity significantly lower subsequent unemployment levels. In other words, unemployed individuals may have a bigger chance to escape unemployment by way of being hired by (new) entrepreneurs than by way of trying to start and maintain a new firm. This, in turn, may be related to the - on average - relatively low human capital levels of unemployed individuals making them less competent to run a firm (van Stel and Storey, 2004). Thus, the results of this paper unequivocally suggest that public policy to generate jobs and reduce unemployment would be best served by focusing more on innovative and highgrowth entrepreneurship than on inducing the unemployed into entering into self-employment. 


\section{REFERENCES}

Acs, Zoltan J., and David B. Audretsch, 2003, Innovation and Technological Change, in: Z.J. Acs and D.B. Audretsch (eds.), Handbook of Entrepreneurship Research, Boston/Dordrecht: Kluwer Academic Publishers, 55-79.

Acs, Zoltan J., Pia Arenius, Michael Hay and Maria Minniti, 2005, Global Entrepreneurship Monitor, 2004 Executive Report, London, UK: London Business School and Wellesley, MA: Babson College.

Audretsch, David B., 1995, Innovation and Industry Evolution, Cambridge, MA: MIT Press.

Audretsch, David B., Martin A. Carree, Adriaan J. van Stel and A. Roy Thurik, 2002, Impeded Industrial Restructuring: The Growth Penalty, Kyklos 55, 81-97.

Audretsch, David B. and Michael Fritsch, 1994, The Geography of Firm Births in Germany, Regional Studies, 28 (4), 359-365.

Audretsch, David B., Isabel Grilo and A. Roy Thurik, 2007, Handbook of Research in Entrepreneurship Policy, Cheltenham, UK and Northampton, MA, US: Edward Elgar Publishing Ltd.

Audretsch, David B. and Max Keilbach, 2004, Entrepreneurship Capital and Economic Performance, Regional Studies 38, 949-959.

Audretsch, David B. and A. Roy Thurik, 2000, Capitalism and Democracy in the $21^{\text {st }}$ Century: from the Managed to the Entrepreneurial Economy, Journal of Evolutionary Economics 10, 17-34.

Audretsch, David B. and A. Roy Thurik, 2001, What is New about the New Economy: Sources of Growth in the Managed and Entrepreneurial Economies, Industrial and Corporate Change 10 (1), 267-315.

Audretsch, David B., A. Roy Thurik, Ingrid Verheul and Sander Wennekers, 2002, Entrepreneurship: Determinants and Policy in a European-US Comparison, Boston/Dordrecht: Kluwer Academic Publishers.

Beesley, M.E. and M.T. Hamilton, 1984, Small Firms' Seedbed Role and the Concept of Turbulence, Journal of Industrial Economics 33, 217-231.

Blanchflower, D.G., 2000, Self-employment in OECD countries, Labour Economics 7, 471-505.

Blanchflower, Danny and Bruce Meyer, 1994, A Longitudinal Analysis of Young Entrepreneurs in Australia and the United States, Small Business Economics 6 (1), 1-20.

Blau, David M., 1987, A Time Series Analysis of Self Employment in the United States, Journal of Political Economy 95 (3), 445-467.

Carree, Martin, 2002, Does Unemployment Affect the Number of Establishments? A Regional Analysis for U.S. States, Regional Studies 36, 389-398.

Carree, Martin, André van Stel, Roy Thurik and Sander Wennekers, 2002, Economic Development and Business Ownership: An Analysis Using Data of 23 OECD Countries in the Period 1976-1996, Small Business Economics 19 (3), 271-290.

Carree, Martin, André van Stel, Roy Thurik and Sander Wennekers, 2007, The Relationship Between Economic Development and Business Ownership Revisited, Entrepreneurship and Regional Development 19 (3), 281-291.

Carree, Martin A. and A. Roy Thurik, 2003, The Impact of Entrepreneurship on Economic Growth, in D.B. Audretsch and Z.J. Acs (eds.), Handbook of Entrepreneurship Research, Boston/Dordrecht: Kluwer Academic Publishers, 437-471.

Carree, Martin A. and A. Roy Thurik, 2007, The Lag Structure of the Impact of Business Ownership on Economic Growth in OECD Countries, Small Business Economics, forthcoming.

Caves, R.E., 1998, Industrial Organization and New Findings on the Turnover and Mobility of Firms, Journal of Economic Literature 36, 1947-1982.

Congregado, E., A. Golpe and J.M. Millán, 2005, Determinantes de la Oferta de Empresarios, in: García, J. and J. Pérez (eds.), Cuestiones Clave de la Economía Española, Perspectivas actuales 2004, Ed. Comares, 165-187.

Dickey, D.A. and W.A. Fuller, 1979, Distribution of the Estimators for Autoregressive Time Series with a Unit Root, Journal of the American Statistical Association 74, 427-431.

Dunne, Timothy, Mark J. Roberts and Larry Samuelson, 1988, Patterns of Firm Entry and Exit in U.S. Manufacturing Industries, RAND Journal of Economics 19, 495-515.

Dunne, Timothy, Mark J. Roberts and Larry Samuelson, 1989, The Growth and Failure of US Manufacturing Plants, Quarterly Journal of Economics 104, 671-698.

Evans, David S., 1987a, The Relationship between Firm Growth, Size and Age: Estimates for 100 Manufacturing Industries, Journal of Industrial Economics 35 (2), 567-581. 
Evans, David S., 1987b, Tests of Alternative Theories of Firm Growth, Journal of Political Economy 95 (4), 657-674.

Evans, David S. and Boyan Jovanovic, 1989, Estimates of a Model of Entrepreneurial Choice under Liquidity Constraints, Journal of Political Economy 97 (3), 657-674.

Evans, David S., and Linda S. Leighton, 1989, The Determinants of Changes in U.S. Self-Employment, 1968-1987, Small Business Economics 1 (2), 111-120.

Evans, David S. and Linda Leighton, 1990, Small Business Formation by Unemployed and Employed Workers, Small Business Economics 2 (4), 319-330.

Fritsch, Michael, and Pamela Mueller, 2004, The Effects of New Business Formation on Regional Development over Time, Regional Studies 38, 961-975.

Garofoli, Gioacchino, 1994, New Firm Formation and Regional Development: The Italian Case, Regional Studies 28 (4), 381-394.

Geroski, Paul A., 1989, Entry, Innovation, and Productivity Growth, Review of Economics and Statistics 71, 572-578.

Geroski, Paul A., 1995, What Do We Know About Entry? International Journal of Industrial Organization 13, 421- 440.

Granger, C.W.J., 1969, Investigating Causal Relations by Econometric Models and Cross-Spectral Methods, Econometrica 37, 424-438.

Grilo, Isabel and Jésus-Maria Irigoyen, 2006, Entrepreneurship in the EU: to Wish and Not to Be, Small Business Economics 26 (4), 305-318.

Grilo, Isabel and Roy Thurik, 2005, Entrepreneurial Engagement Levels in the European Union, International Journal of Entrepreneurship Education 3 (2), 143-168.

Hall, Bronwyn H., 1987, The Relationship between Firm Size and Firm Growth in the U.S. Manufacturing Sector, Journal of Industrial Economics 35, June, 583-605.

Hamilton, Robert T., 1989, Unemployment and Business Formation Rates: Reconciling Time Series and Cross Section Evidence, Environment and Planning 21, 249-255.

Hart, P.E. and N. Oulton, 1999, Gibrat, Galton and Job Generation, International Journal of the Economics of Business 6, 149-164.

Hayek, F.A., 1945, The Use of Knowledge in Society, American Economic Review 35, 519-530.

Highfield, R. and Robert Smiley, 1987, New Business Starts and Economic Activity: An Empirical Investigation, International Journal of Industrial Organization 5, 51-66.

Hurst, E. and A. Lusardi, 2004, Liquidity Constraints, Household Wealth and Entrepreneurship, Journal of Political Economy 112 (2), 319-347.

Johansson, E., 2000, Self-Employment and Liquidity Constraints: Evidence from Finland, Scandinavian Journal of Economics 102, 123-134.

Kirzner, Israel M., 1973, Competition and Entrepreneurship, Chicago: University of Chicago Press.

Klomp, Luuk, Enrico Santarelli and Roy Thurik, 2006, Gibrat's Law: an Overview of the Empirical Literature, in E. Santarelli (ed.), Entrepreneurship, Growth, and Innovation: the Dynamics of Firms and Industries: International Studies in Entrepreneurship, Berlin: Springer Science, 41-73.

Knight, Frank H., 1921, Risk, Uncertainty and Profit, New York: Houghton Mifflin.

Lin, Zhengxi, Marilyn E. Manser and Garnett Picot, 1998, The Role of Self-Employment in Job Creation In Canada and the U.S., OECD-CERF-CILN International Conference on Self-Employment, Burlington, Ontario, Canada.

Mueller, Stephen L. and Anisya S. Thomas, 2000, Culture and Entrepreneurial Potential: A Nine Country Study of Locus of Control and Innovativeness, Journal of Business Venturing 16, 51-75.

Nickell, S.J., 1996, Competition and Corporate Performance, Journal of Political Economy 104, 724-746.

Nickell, S., P. Nicolitsas and N. Dryden, 1997, What Makes Firms Perform Well? European Economic Review 41, 783-796.

Oxenfeldt, A., 1943, New Firms and Free Enterprise, Washington, D.C.: American Council on Public Affairs.

Parker, Simon C., 2004, The Economics of Self-Employment and Entrepreneurship, Cambridge, UK: Cambridge University Press.

Pfeiffer, F. and Reize, F., 2000, Business Start-ups by the Unemployed - an Econometric Analysis Based on Firm Data, Labour Economics 7 (5), 629-663.

Reynolds, P., B. Miller and W.R. Maki, 1995, Explaining Regional Variation in Business Births and Deaths: U.S. 1976-1988, Small Business Economics 7 (5), 389-707. 
Reynolds, Paul, David J. Storey and Paul Westhead, 1994, Cross-National Comparisons of the Variation in New Firm Formation Rates, Regional Studies 28 (4), 443-456.

Schumpeter, Joseph A., 1934, The Theory of Economic Development, Cambridge, MA: Harvard University Press.

Shane, S., L. Kolvereid and P. Westhead, 1991, An Exploratory Examination of the Reasons Leading to New Firm Formation Across Country and Gender, Journal of Business Venturing 6, 431-446.

Sims, Christopher A., 1980, Macroeconomics and Reality, Econometrica 48, 1-48.

Stel, André van, 2005, COMPENDIA: Harmonizing Business Ownership Data Across Countries and Over Time, International Entrepreneurship and Management Journal 1 (1), 105-123.

Stel, André van, Martin Carree and Roy Thurik, 2005, The Effect of Entrepreneurial Activity on National Economic Growth, Small Business Economics 24 (3), 311-321.

Stel, Adriaan J. van, and David J. Storey, 2004, The Link between Firm Births and Job Creation: Is there a Upas Tree Effect? Regional Studies 38 (8), 893-909.

Stel, André van, and Kashifa Suddle, 2007, The Impact of New Firm Formation on Regional Development in the Netherlands, Small Business Economics, forthcoming.

Storey, David J., 1991, The Birth of New Firms - Does Unemployment Matter? A Review of the Evidence, Small Business Economics 3 (3), 167-178.

Sutton, John, 1997, Gibrat's Legacy, Journal of Economic Literature 35, 40-59.

Thurik, Roy, 1999, The Dutch Polder Model: Shifting from the Managed Economy to the Entrepreneurial Economy, Annual Meeting of the American Economic Association New York, NY, January 3-5, 1999.

Yamawaki, Hideki, 1990, The Effects of Business Conditions on Net Entry: Evidence from Japan, in P.A. Geroski and J. Schwalbach (eds.), Entry and Market Contestability: An International Comparison, Oxford: Basil Blackwell, 168-186.

Yu, Tony Fu-Lai, 1998, Adaptive Entrepreneurship and the Economic Development of Hong Kong, World Development 26 (5), 897-911. 
Table 1: Ranking of countries with respect to change in self-employment rate (in \% points) for periods 1978-86 and 1986-94

\begin{tabular}{lccc}
\hline Country & Year $(\mathrm{t})$ & $E_{t}-E_{t-8}$ & $U_{t+8}-U_{t}$ \\
\hline Portugal & & & -2.0 \\
Ireland & 1994 & 4.5 & -10.3 \\
Iceland & 1994 & 2.6 & -1.4 \\
United Kingdom & 1994 & 2.6 & -4.5 \\
Italy & 1994 & 2.2 & 0.5 \\
Canada & 1986 & 2.1 & -2.6 \\
& 1994 & 2.1 & -1.5 \\
Portugal & & & 0.5 \\
Austria & 1986 & -0.9 & 0.2 \\
Luxembourg & 1986 & -1.1 & 1.1 \\
Luxembourg & 1994 & -1.1 & 2.6 \\
Denmark & 1986 & -1.4 & 2.5 \\
Japan & 1986 & -1.6 & -2.0 \\
\hline
\end{tabular}

Source: Compendia 2002.1

Note: $E_{t}$ and $U_{t}$ are the self-employment and unemployment rates in period $\mathrm{t}$ 
Table 2: Estimation results VAR model for 1, 2 and 3 four-year period time lags

\begin{tabular}{|c|c|c|c|c|c|c|}
\hline & & $\begin{array}{c}\text { Model Ia } \\
1 \text { lag }\end{array}$ & $\begin{array}{c}\text { Model Ib } \\
1 \text { lag }\end{array}$ & $\begin{array}{c}\text { Model IIa } \\
2 \text { lags }\end{array}$ & $\begin{array}{l}\text { Model IIb } \\
2 \text { lags }\end{array}$ & $\begin{array}{l}\text { Model III } \\
3 \text { lags }\end{array}$ \\
\hline \multicolumn{7}{|c|}{ equation (6): dependent variable $U_{t}-U_{t-4}$} \\
\hline Constant & $\alpha$ & $\begin{array}{c}0.030 * * \\
(7.3)\end{array}$ & $\begin{array}{c}0.005 \\
(1.1) \\
\end{array}$ & $\begin{array}{c}0.007 \\
(1.4)\end{array}$ & $\begin{array}{c}-0.008 \\
(1.8)\end{array}$ & $\begin{array}{c}-0.009 \\
(1.8)\end{array}$ \\
\hline$E_{t-4}-E_{t-8}$ & $\beta_{1}$ & $\begin{array}{c}-0.587 * \\
(2.5)\end{array}$ & $\begin{array}{c}-0.462 \\
(1.8)\end{array}$ & $\begin{array}{c}0.091 \\
(0.3)\end{array}$ & $\begin{array}{c}0.309 \\
(1.0)\end{array}$ & $\begin{array}{c}0.279 \\
(0.9)\end{array}$ \\
\hline$E_{t-8}-E_{t-12}$ & $\beta_{2}$ & & & $\begin{array}{c}-1.13 * * \\
(3.8)\end{array}$ & $\begin{array}{c}-1.06 * * \\
(3.4)\end{array}$ & $\begin{array}{c}-0.793 * \\
(2.4)\end{array}$ \\
\hline$E_{t-12}-E_{t-16}$ & $\beta_{3}$ & & & & & $\begin{array}{c}-0.630 \\
(1.8)\end{array}$ \\
\hline$U_{t-4}-U_{t-8}$ & $\gamma_{1}$ & $\begin{array}{c}-0.143 \\
(1.6)\end{array}$ & $\begin{array}{l}-0.175 \\
(1.9)\end{array}$ & $\begin{array}{c}-0.246 * * \\
(2.7)\end{array}$ & $\begin{array}{c}-0.234 * \\
(2.3)\end{array}$ & $\begin{array}{c}-0.334 * * \\
(3.1)\end{array}$ \\
\hline$U_{t-8}-U_{t-12}$ & $\gamma_{2}$ & & & $\begin{array}{c}-0.027 \\
(0.3)\end{array}$ & $\begin{array}{c}-0.112 \\
(1.1)\end{array}$ & $\begin{array}{c}-0.157 \\
(1.5)\end{array}$ \\
\hline$U_{t-12}-U_{t-16}$ & $\gamma_{3}$ & & & & & $\begin{array}{c}0.093 \\
(0.8)\end{array}$ \\
\hline \multicolumn{2}{|c|}{ R-squared } & 0.439 & 0.319 & 0.403 & 0.444 & 0.474 \\
\hline \multicolumn{2}{|c|}{$\begin{array}{l}\text { P-value Granger cau- } \\
\text { sality test }\end{array}$} & 0.015 & 0.076 & 0.000 & 0.003 & 0.002 \\
\hline \multicolumn{7}{|c|}{ equation (7): dependent variable $E_{t}-E_{t-4}$} \\
\hline Constant & $\kappa$ & $\begin{array}{c}0.004 * * \\
(2.7)\end{array}$ & $\begin{array}{c}-0.001 \\
(0.3) \\
\end{array}$ & $\begin{array}{c}-0.002 \\
(1.5) \\
\end{array}$ & $\begin{array}{l}-0.000 \\
(0.3)\end{array}$ & $\begin{array}{c}-0.001 \\
(0.7) \\
\end{array}$ \\
\hline$U_{t-4}-U_{t-8}$ & $\lambda_{1}$ & $\begin{array}{c}0.031 \\
(1.1) \\
\end{array}$ & $\begin{array}{l}0.042 \\
(1.4)\end{array}$ & $\begin{array}{c}0.067 * \\
(2.2)\end{array}$ & $\begin{array}{l}0.057 \\
(1.5) \\
\end{array}$ & $\begin{array}{c}0.046 \\
(1.1)\end{array}$ \\
\hline$U_{t-8}-U_{t-12}$ & $\lambda_{2}$ & & & $\begin{array}{c}0.090 * * \\
(2.8)\end{array}$ & $\begin{array}{c}0.088 * \\
(2.4)\end{array}$ & $\begin{array}{c}0.093 * \\
(2.4)\end{array}$ \\
\hline$U_{t-12}-U_{t-16}$ & $\lambda_{3}$ & & & & & $\begin{array}{c}0.056 \\
(1.3)\end{array}$ \\
\hline$E_{t-4}-E_{t-8}$ & $\mu_{1}$ & $\begin{array}{c}0.416^{* *} \\
(5.4) \\
\end{array}$ & $\begin{array}{c}0.422 * * \\
(5.0)\end{array}$ & $\begin{array}{c}0.329 * * \\
(3.5)\end{array}$ & $\begin{array}{c}0.289 * \\
(2.5) \\
\end{array}$ & $\begin{array}{c}0.246 * \\
(2.0) \\
\end{array}$ \\
\hline$E_{t-8}-E_{t-12}$ & $\mu_{2}$ & & & $\begin{array}{c}0.167 \\
(1.7)\end{array}$ & $\begin{array}{c}0.213 \\
(1.8)\end{array}$ & $\begin{array}{c}0.220 \\
(1.7)\end{array}$ \\
\hline$E_{t-12}-E_{t-16}$ & $\mu_{3}$ & & & & & $\begin{array}{c}0.016 \\
(0.1) \\
\end{array}$ \\
\hline \multicolumn{2}{|c|}{ R-squared } & 0.340 & 0.333 & 0.385 & 0.366 & 0.379 \\
\hline \multicolumn{2}{|c|}{$\begin{array}{l}\text { P-value Granger cau- } \\
\text { sality test }\end{array}$} & 0.284 & 0.176 & 0.006 & 0.044 & 0.074 \\
\hline \multicolumn{2}{|l|}{$\mathrm{N}$} & 138 & 115 & 115 & 92 & 92 \\
\hline \multicolumn{2}{|l|}{ Loglikelihood } & -563.9 & -469.0 & -457.0 & -368.6 & -364.7 \\
\hline
\end{tabular}

Note: Absolute t-values are between brackets. The results are from a weighted vector autoregression (VAR) with population as weighting variable. Coefficients for year dummies are not reported.

* significant at 0.05 level.

** significant at 0.01 level. 
Table 3: Impulse response functions for unit changes in self-employment and unemployment

\begin{tabular}{l|cc|cc}
\hline \multirow{2}{*}{ Lag (years) } & \multicolumn{2}{|l|}{$\begin{array}{l}\text { Effect of unit change in self-employ- } \\
\text { ment on unemployment (equation 6) }\end{array}$} & \multicolumn{2}{l}{$\begin{array}{l}\text { Effect of unit change in unemployment } \\
\text { on self-employment (equation 7) }\end{array}$} \\
\cline { 2 - 5 } & Direct effect & Cumulative effect & Direct effect & Cumulative effect \\
\hline 4 & 0.09 & 0.09 & 0.067 & 0.067 \\
8 & -1.12 & -1.03 & 0.095 & 0.163 \\
12 & -0.07 & -1.10 & 0.023 & 0.186 \\
16 & -0.26 & -1.36 & 0.022 & 0.208 \\
Asymptot & & -1.29 & & 0.190 \\
\hline
\end{tabular}

Note: Effects are based on model IIa

Figure 1: Impulse response function for unit change in self-employment, model IIa Impact on unemployment

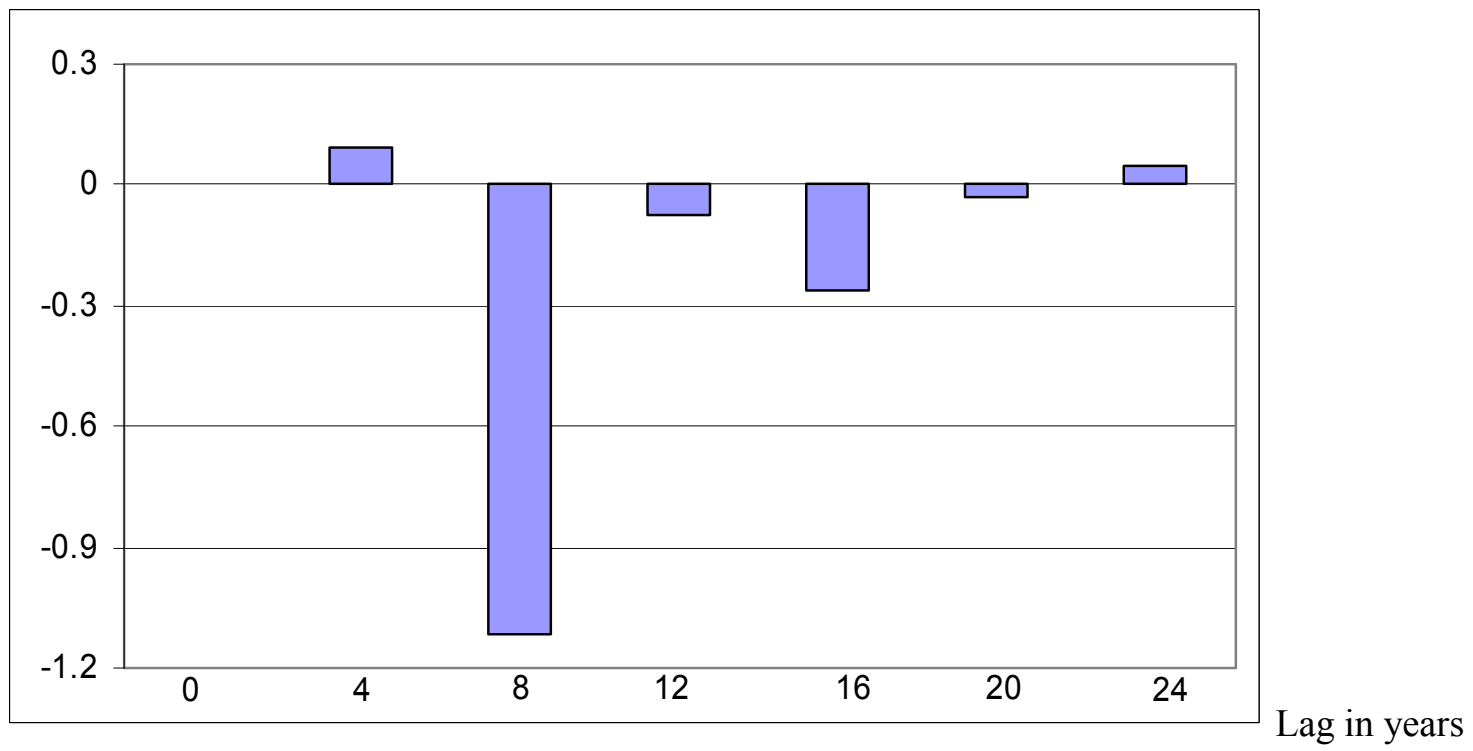

